\title{
Simulation of proposed increases in ground-water withdrawals from the Atlantic City 800-foot sand, New Jersey Coastal Plain
}

By Daryll A. Pope

Prepared in cooperation with the New Jersey Department of Environmental Protection

Scientific Investigations Report 2006-5114 


\section{U.S. Department of the Interior DIRK KEMPTHORNE, Secretary \\ U.S. Geological Survey \\ P. Patrick Leahy, Acting Director}

U.S. Geological Survey, Reston, Virginia: 2006

For product and ordering information:

World Wide Web: http://www.usgs.gov/pubprod

Telephone: 1-888-ASK-USGS

For more information on the USGS--the Federal source for science about the Earth, its natural and living resources, natural hazards, and the environment:

World Wide Web: http://www.usgs.gov

Telephone: 1-888-ASK-USGS

Any use of trade, product, or firm names is for descriptive purposes only and does not imply endorsement by the U.S. Government.

Although this report is in the public domain, permission must be secured from the individual copyright owners to reproduce any copyrighted materials contained within this report. 


\section{Contents}

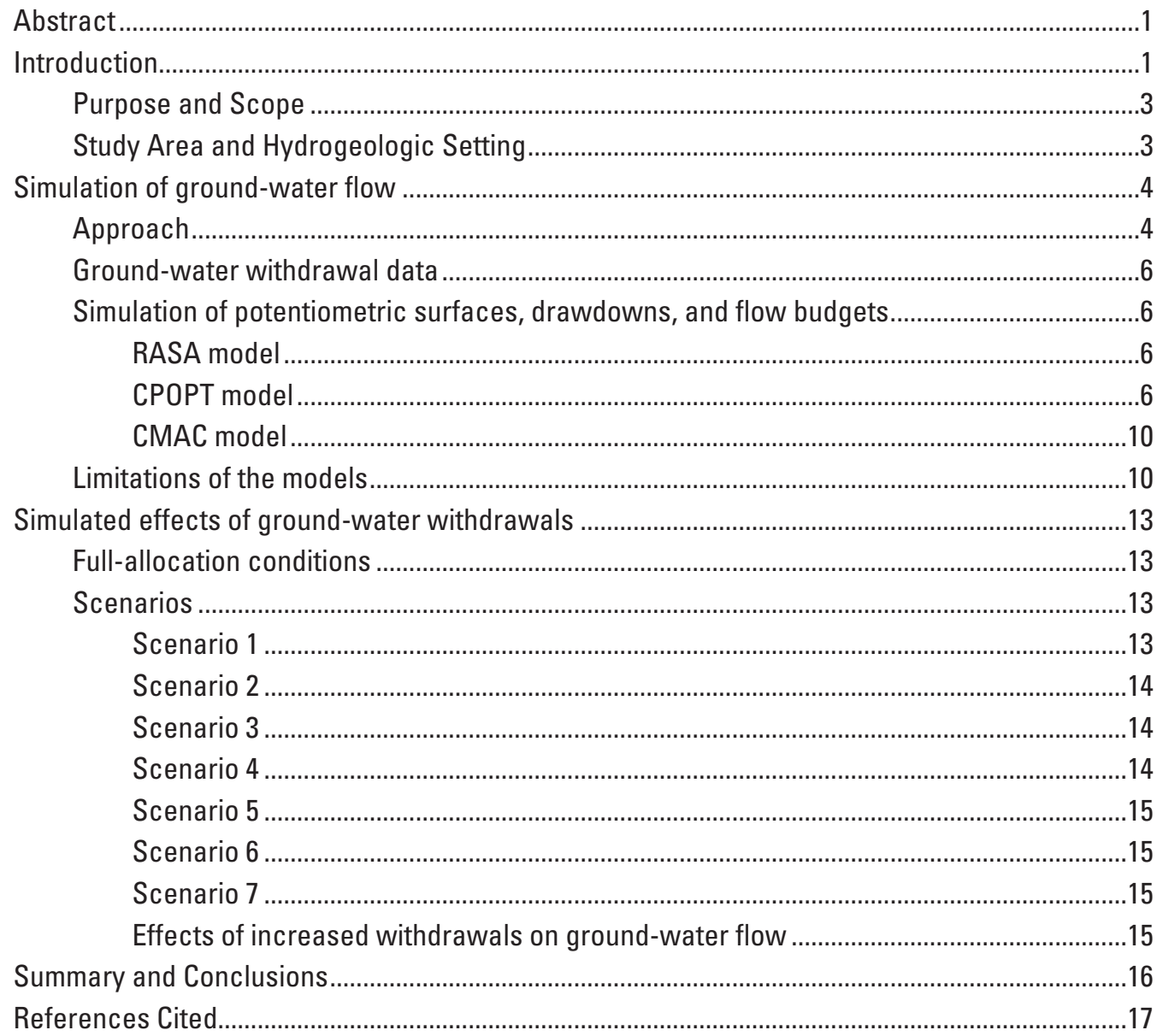

\section{Figures}

1. Map showing location of the study area, New Jersey Coastal Plain................................2

2. Diagrammatic hydrogeologic section $A-A^{\prime}$ through the New Jersey Coastal Plain .........4

3-5. Maps showing-

3. Estimated potentiometric surfaces for the Atlantic City 800-foot sand, New Jersey, using the RASA model

4. Simulated drawdown from simulated 1998 conditions to full-allocation conditions and incremental drawdown from the previous scenario for scenarios 1 through 7, Atlantic City 800-foot sand, New Jersey.

5. Estimated potentiometric surfaces resulting from full-allocation conditions and drawdown from full-allocation levels in successive scenarios 1 through 7 that each include the drawdown from previous scenarios, Atlantic City 800 -foot sand, New Jersey 
6. Graphs showing flow budgets for the confined freshwater part of the Atlantic City 800-foot sand, New Jersey, under full-allocation conditions and scenarios 1 through 7: (a) flow from sources, (b) change from previous scenario,

(c) increase from full-allocation

7. Conceptual cross section showing flow-budget area and flow terms for the Atlantic City 800-foot sand, New Jersey...

8. Map showing simulated potentiometric surfaces and pathlines from the 250-milligram-per-liter isochlor using the Cape May Atlantic City 800-foot sand model, Atlantic City 800-foot sand, New Jersey......

\section{Tables}

1. Description of model scenarios for the Atlantic City 800-foot sand and the deep part of the Kirkwood-Cohansey aquifer system, New Jersey.

2. Travel times of particles from the 250-milligram-per-liter isochlor to production wells, Atlantic City 800-foot sand, New Jersey. 


\section{Conversion Factors and Datums}

\begin{tabular}{|c|c|c|}
\hline Multiply & By & To obtain \\
\hline \multicolumn{3}{|c|}{ Length } \\
\hline inch (in.) & 25.4 & millimeter $(\mathrm{mm})$ \\
\hline foot $(\mathrm{ft})$ & 0.3048 & $\operatorname{meter}(\mathrm{m})$ \\
\hline mile (mi) & 1.609 & kilometer $(\mathrm{km})$ \\
\hline \multicolumn{3}{|c|}{ Area } \\
\hline square foot $\left(\mathrm{ft}^{2}\right)$ & 0.09290 & square meter $\left(\mathrm{m}^{2}\right)$ \\
\hline square mile $\left(\mathrm{mi}^{2}\right)$ & 2.590 & square kilometer $\left(\mathrm{km}^{2}\right)$ \\
\hline \multicolumn{3}{|c|}{ Volume } \\
\hline gallon (gal) & 3.785 & liter $(\mathrm{L})$ \\
\hline cubic foot $\left(\mathrm{ft}^{3}\right)$ & 7.4805 & gallon (gal) \\
\hline \multicolumn{3}{|c|}{ Flow rate } \\
\hline million gallons per day (Mgal/d) & 0.04381 & cubic meter per second $\left(\mathrm{m}^{3} / \mathrm{s}\right)$ \\
\hline million gallons per year (Mgal/yr) & 15.99 & cubic meter per second $\left(\mathrm{m}^{3} / \mathrm{s}\right)$ \\
\hline \multicolumn{3}{|c|}{ Hydraulic conductivity } \\
\hline foot per day $(\mathrm{ft} / \mathrm{d})$ & 0.3048 & meter per day $(\mathrm{m} / \mathrm{d})$ \\
\hline \multicolumn{3}{|c|}{ Transmissivity* } \\
\hline foot squared per day $\left(\mathrm{ft}^{2} / \mathrm{d}\right)$ & 0.09290 & meter squared per day $\left(\mathrm{m}^{2} / \mathrm{d}\right)$ \\
\hline
\end{tabular}

Vertical coordinate information is referenced to the National Geodetic Vertical Datum of 1929 (NGVD 1929).

Horizontal coordinate information is referenced to the North American Datum of 1983 (NAD 83).

Altitude, as used in this report, refers to distance above the vertical datum.

*Transmissivity: The standard unit for transmissivity is cubic foot per day per square foot times foot of aquifer thickness $\left[\left(\mathrm{ft}^{3} / \mathrm{d}\right) / \mathrm{ft}^{2}\right] \mathrm{ft}$. In this report, the mathematically reduced form, foot squared per day $\left(\mathrm{ft}^{2} / \mathrm{d}\right)$, is used for convenience. 


\title{
Simulation of proposed increases in ground-water withdrawals from the Atlantic City 800-foot sand, New Jersey Coastal Plain
}

\author{
By Daryll A. Pope
}

\section{Abstract}

The confined Atlantic City 800-foot sand and the unconfined Kirkwood-Cohansey aquifer system (surficial aquifer) are major sources of water for southeastern New Jersey. Because of recent concerns about streamflow depletion resulting from ground-water withdrawals and the potential ecological effects on stream habitat in the area, the focus on future withdrawals has been shifted away from the surficial aquifer to the confined Atlantic City 800-foot sand until the effects of increased withdrawals from the surficial aquifer can be investigated. A study was conducted to evaluate the effects of seven proposed increases in ground-water withdrawals from the Atlantic City 800-foot sand and the Kirkwood-Cohansey aquifer system on the Atlantic City 800-foot sand. The proposed withdrawals are increases above the 2004 allocated rates (full allocation). The effects of full-allocation ground-water withdrawals and the cumulative effect of withdrawals for each of seven proposed increases in withdrawals were simulated using three previously published ground-water flow models: the New Jersey Coastal Plain Regional Aquifer System Analysis model, the Coastal Plain Optimization model, and a model of the Atlantic City 800-foot sand in Atlantic County, New Jersey. These models were used to simulate changes in water levels, the source supplying the increased ground-water flow, and the effects on saltwater movement towards production wells in Cape May County as a result of the proposed increased withdrawals at proposed or existing wells.

The results of the simulations represent the effects of the proposed increase from full-allocation withdrawals to an additional $1,825 \mathrm{Mgal} / \mathrm{yr}$ (million gallons per year) from the Atlantic City 800-foot sand and an additional 1,045 Mgal/yr from the deep part of the Kirkwood-Cohansey aquifer system near the updip limit of the Atlantic City 800-foot sand. Most of the simulated decline in water levels in Atlantic County occurred as the result of the proposed increased withdrawals simulated for the New Jersey American Water Company wells. Simulated declines in water levels in Cape May were caused mainly by the simulated increased withdrawals for the Cape May City Desalination Plant wells. The additional water to supply the proposed increases in the scenarios was primarily horizontal flow from the unconfined updip part of the Kirkwood-Cohansey aquifer system, which accounted for 63 percent of the inflow, and flow from the overlying Kirkwood-Cohansey aquifer system into the Atlantic City 800 -foot sand, which supplied 27 percent of the additional water. Because the withdrawals were made from the confined aquifer and the deeper part of the unconfined aquifer, the effect on streamflow was substantially less than would have occurred had the withdrawals been made directly from the shallower parts of the unconfined aquifer. The travel times from the $250-\mathrm{mg} / \mathrm{L}$ isochlor to production wells in Stone Harbor were longer as a result of all the additional withdrawals. For some scenarios, withdrawals in Atlantic County caused the saltwater to move slightly faster towards the production wells. These effects were offset by the increase in travel time caused by the potential increased withdrawals simulated for the Cape May City desalination wells, which either diverted water towards the desalination wells or increased the travel time towards production wells.

\section{Introduction}

The confined Atlantic City 800-foot sand and the overlying unconfined Kirkwood-Cohansey aquifer system are major sources of water for southeastern New Jersey (fig. 1). Water levels in the Atlantic City 800-foot sand near Atlantic City were as low as $100 \mathrm{ft}$ below NGVD of 1929 in 1998 and have been slowly declining. There are concerns about the longterm sustainability of the Atlantic City 800-foot sand and the ability to supply projected future ground-water withdrawals. In addition, recent concerns about streamflow depletion due to ground-water withdrawals from the unconfined KirkwoodCohansey aquifer system and potential ecologic effects on stream habitat in the area, including part of the Pinelands National Reserve, have shifted focus on future withdrawals away from the surficial aquifer to the confined Atlantic City 800-foot sand until the effects of increased withdrawals from the surficial aquifer can be studied. In 2004, a large number of requests for increased withdrawals (in excess of the previously 


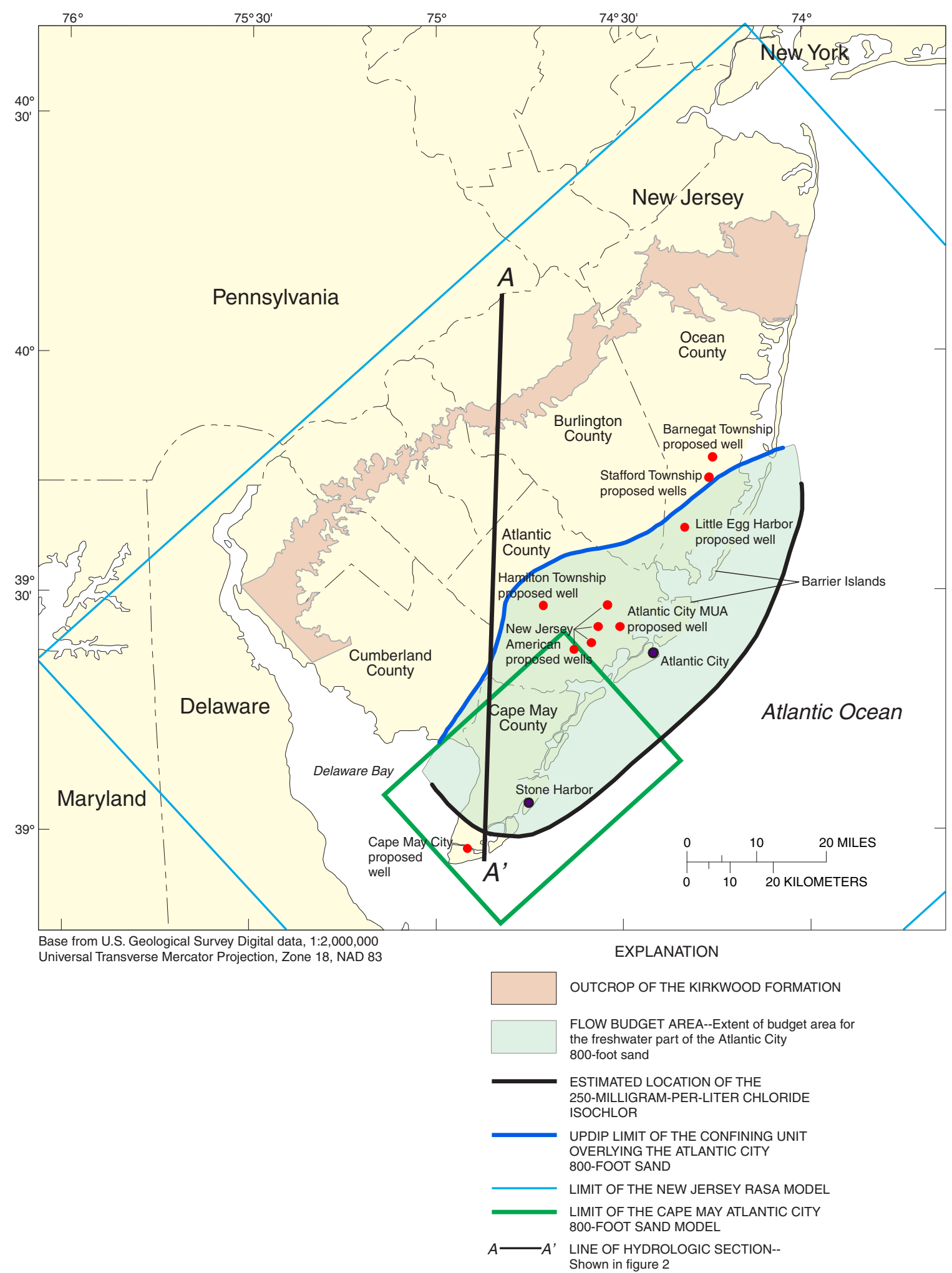

Figure 1. Location of the study area, New Jersey Coastal Plain. 
permitted allocation) from the Atlantic City 800-foot sand were received and are under consideration by the New Jersey Department of Environmental Protection (NJDEP). Water managers want to be able to evaluate the cumulative and incremental effects of these proposed increases on the Atlantic City 800 -foot sand. Therefore, the U.S. Geological Survey (USGS), in cooperation with the NJDEP, conducted a study to simulate the effects of these proposed increases in withdrawals from this aquifer.

Threats to the sustainable water supply in the Atlantic City 800-foot sand include saltwater intrusion from the Atlantic Ocean, saltwater intrusion from Delaware Bay, and potential effects of withdrawals from the Atlantic City 800-foot sand on the overlying Kirkwood-Cohansey aquifer system. Saltwater intrusion is possible in Cape May where the $250-\mathrm{mg} / \mathrm{L}$ isochlor is located onshore (fig. 1) and the Atlantic City 800-foot sand crops out beneath Delaware Bay. Although the $250-\mathrm{mg} / \mathrm{L}$ isochlor is at least 5 miles offshore of Atlantic City (fig. 1) and is considered a long-term threat to water quality, increased withdrawals from the Atlantic City 800-foot sand might increase the rate of saltwater intrusion in Atlantic County from offshore areas. Withdrawals from the Atlantic City 800-foot sand could contribute to streamflow depletion in the Kirkwood-Cohansey aquifer system.

The USGS used three published ground-water flow models of the New Jersey Coastal Plain to simulate the effects of withdrawals from the Atlantic City 800-foot sand. The New Jersey Coastal Plain Regional Aquifer System Analysis (RASA) model (Voronin, 2003) was used to evaluate the decline in water levels that could result from the proposed increased withdrawals. The RASA model also was used to produce flow budgets for the freshwater part of the aquifer to determine the source of water for each of the proposed increases in withdrawals. The model of the Atlantic City 800-foot sand in Cape May County (CMAC) (Voronin and others, 1996) was used to determine the effects of the various proposed increases in withdrawals on the rate and direction of water movement from the current location of the $250-\mathrm{mg} / \mathrm{L}$ isochlor. The New Jersey Coastal Plain Optimization model (CPOPT) (Pope and Gordon, 1999) was used to provide boundary conditions to the smaller-scale CMAC model. The CPOPT model simulates the location of an idealized sharp interface between freshwater and saltwater in the Coastal Plain aquifers. Because the interface is closer to the shore south and east of Cape May, the CPOPT model provides more realistic boundary flows than the RASA model.

\section{Purpose and Scope}

This report describes simulations in which increased withdrawals were made from the Atlantic City 800-foot sand and the unconfined Kirkwood-Cohansey aquifer system to determine the effects on the Atlantic City 800-foot sand. Fullallocation conditions were simulated to determine conditions that would occur if all wells in the Atlantic City 800-foot sand were pumped at the permitted allocation rate (2004). Output from the full-allocation simulation serves as a baseline for comparison with the output from the seven alternate withdrawal scenarios. The seven scenarios are described along with the incremental and cumulative effects of the increased withdrawals on the water levels in the Atlantic City 800-foot sand and on sources of water to wells. The report describes the models used to simulate the withdrawal scenarios and provides details on the proposed increases in withdrawals. Output from the simulations - water levels, drawdowns, flow budgets, and travel times of particles from saltwater areas to wells - are presented in figures and tables.

\section{Study Area and Hydrogeologic Setting}

The study area includes Atlantic and Cape May Counties, and parts of Ocean and Burlington Counties and is defined by the limits of the Atlantic City 800-foot sand in the Coastal Plain of New Jersey (fig. 1). The study area can be defined as the freshwater part of the Atlantic City 800-foot sand from the updip limit of the confining unit overlying the Atlantic City 800 -foot sand to the $250-\mathrm{mg} / \mathrm{L}$ isochlor (fig. 1).

The hydrogeologic framework used in this report is that developed for the USGS New Jersey Coastal Plain RASA Project (Zapecza, 1989). The New Jersey Coastal Plain is a seaward-dipping wedge of unconsolidated sediments that range in age from Cretaceous to Holocene. These sediments consist mainly of clay, silt, sand, and gravel. Units that are mostly sand and gravel are permeable and are considered aquifers, and those that are mostly silt and clay are relatively impermeable and are considered confining units. The aquifers of interest in this report are the Piney Point aquifer, the Atlantic City 800-foot sand, and the Kirkwood-Cohansey aquifer system (fig. 2). The Kirkwood-Cohansey aquifer system is an unconfined aquifer composed of sediments of the Cohansey and Kirkwood Formations except where overlain by Quaternary sediments in Cape May County. In updip areas, the Kirkwood Formation constitutes the deeper part of the aquifer system. In downdip areas, the Kirkwood Formation is confined and is referred to as the Atlantic City 800-foot sand. Major confining units are the composite confining unit which separates the Atlantic City 800-foot sand and the underlying Piney Point aquifer and the confining unit overlying the Atlantic City 800 -foot sand. The outcrop of the Kirkwood-Cohansey aquifer system and the updip limit of the confining unit overlying the Atlantic City 800-foot sand are shown in figure 1. Further information on the hydrogeology of the Kirkwood-Cohansey aquifer system and the Atlantic City 800-foot sand is available in McAuley and others (2001) and Sugarman (2001).

The potentiometric surface of the Atlantic City 800-foot sand ranges in altitude from $15 \mathrm{ft}$ above NGVD of 1929 near the updip edge of the overlying confining unit to greater than $100 \mathrm{ft}$ below NGVD of 1929 within the cone of depression centered near Atlantic City in 1998 (Lacombe and Rosman, 2001, sheet 3 ). The aquifer is recharged by vertical flow 


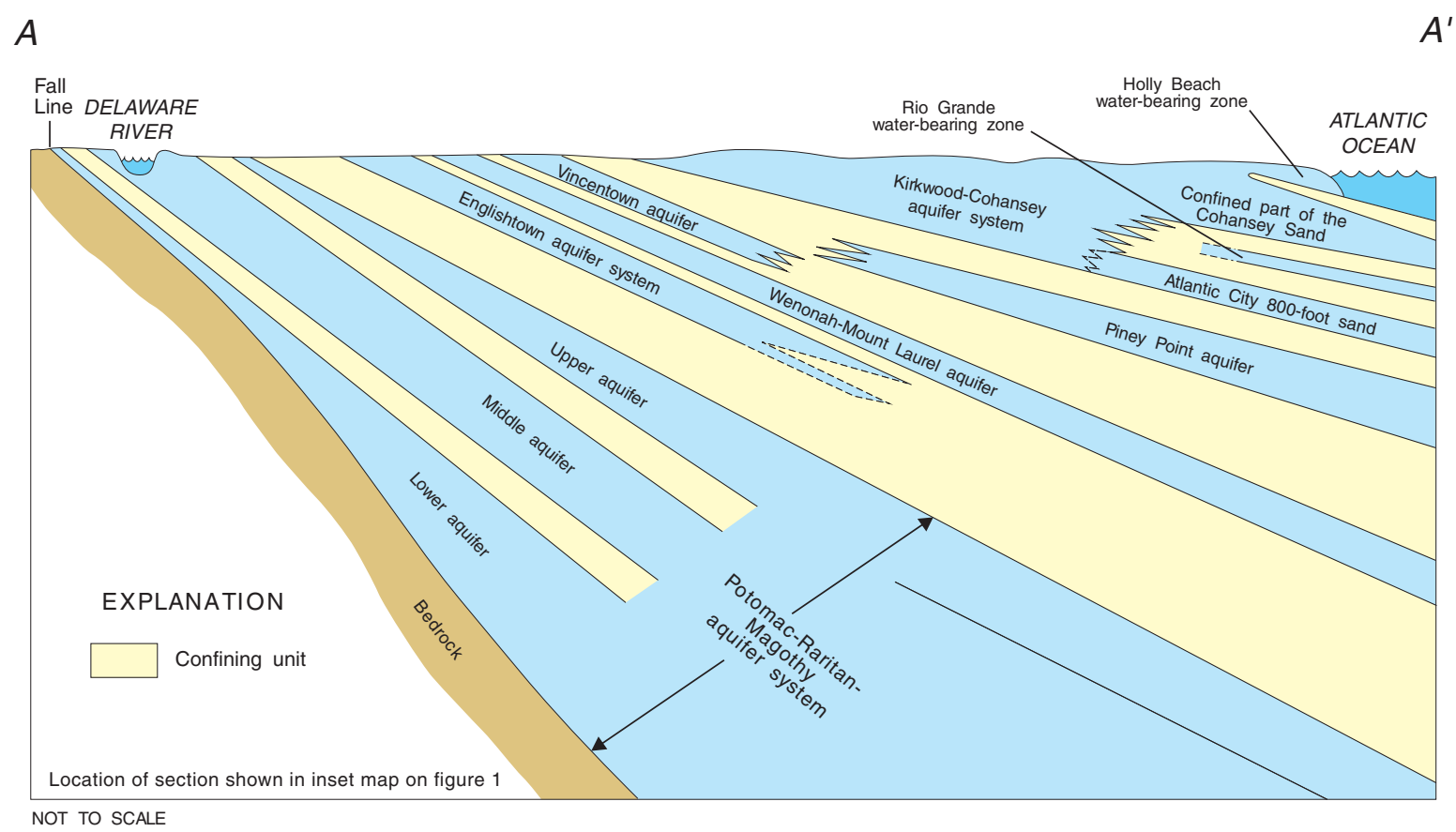

Figure 2. Diagrammatic hydrogeologic section A-A' through the New Jersey Coastal Plain. (Modified from Zapecza and others, 1987)

from the overlying Kirkwood-Cohansey aquifer system. This recharge occurs throughout the extent of the aquifer, but is much more significant near the updip limit of the confining unit overlying the Atlantic City 800 -foot sand where the two aquifers are in direct contact and where the overlying confining unit is thinner and more permeable. The aquifer also is recharged by lateral flow from the Kirkwood-Cohansey aquifer system in areas near the updip limit of the overlying confining unit.

\section{Simulation of ground-water flow}

\section{Approach}

The effects of full-allocation ground-water withdrawals (the maximum allowed by the NJDEP permit) and the cumulative effects of withdrawals for each of seven proposed increases in withdrawals from the Atlantic City 800-foot sand were simulated. The scenarios are listed in table 1 in the order in which they were simulated, along with the current allocation, the proposed increase in withdrawals for each scenario and details about the withdrawal rates for the wells. All scenario simulations were based on full-allocation withdrawals from the Atlantic City 800-foot sand. The full-allocation conditions serve as a baseline for scenarios 1 through 7 . The simulation of additional withdrawals for each scenario was cumulative; each scenario included the increase described for that scenario as well as the increases for all previous scenarios. The simulations were done using three different ground-water flow models, the revised New Jersey Coastal Plain Regional Aquifer Systems Analysis model (RASA) (Voronin, 2003), the Coastal Plain Optimization model (CPOPT) (Pope and Gordon, 1999), and a model of the Atlantic City 800-foot sand in Atlantic County (CMAC) (Voronin and others, 1996). The order of the scenarios was set by NJDEP to reflect the order in which they would be considering the proposed permit modifications.

The RASA model was used to simulate the effects of the increased withdrawals throughout the Atlantic City 800-foot sand. The Atlantic City 800 -foot sand in the RASA model is the confined part of the lower Kirkwood-Cohansey aquifer system and confined Kirkwood aquifer model layer. The scale of the model is fine enough to simulate existing and additional proposed wells adequately. The output from the RASA model is displayed by presenting potentiometric surfaces and drawdown from the scenarios and flow budgets for the freshwater part of the Atlantic City 800-foot sand. The original calibration of the RASA model, including a description of the model boundary conditions, is documented in Martin (1998). Revisions to the model and a recalibration to 1998 conditions are described in Voronin (2003).

The CPOPT model was used to provide boundary conditions to the CMAC model of the Atlantic City 800-foot sand in Cape May. The CPOPT model also was used to simulate the freshwater/saltwater interface (50 percent of seawater concentration) and, therefore, provide adequate boundary flows to the CMAC submodel. The grid size of the CPOPT model, however, was too coarse to use for simulations of existing and proposed withdrawals throughout the Atlantic City 800-foot sand. The simulation of the sharp interface and calibration 
Table 1. Description of model scenarios for the Atlantic City 800-foot sand and the deep part of the Kirkwood-Cohansey aquifer system, New Jersey.

[Total withdrawals for scenarios 1 through 7 are cumulative; each scenario includes proposed increases from all previous scenarios. NJDEP, New Jersey Department of Environmental Protection; Mgal/yr, million gallons per year; cfs, cubic feet per second; MUA, Municipal Utility Authority; confined, withdrawals were made from Atlantic City 800-foot sand; unconfined, withdrawals were made from the deep part of the unconfined Kirkwood-Cohansey aquifer system; NA, not available.]

\begin{tabular}{|c|c|c|c|c|c|c|c|}
\hline $\begin{array}{l}\text { Scenario } \\
\text { identifier }\end{array}$ & Description & $\begin{array}{l}\text { NJDEP water } \\
\text { allocation } \\
\text { permit number }\end{array}$ & Characteristics & $\begin{array}{l}\text { Existing } \\
\text { allocation rate } \\
(2005) \\
(\mathrm{Mgal} / \mathrm{yr})\end{array}$ & $\begin{array}{l}\text { Proposed } \\
\text { increased } \\
\text { rate } \\
(\mathrm{Mgal} / \mathrm{yr})\end{array}$ & $\begin{array}{l}\text { Total rate } \\
\text { for permit } \\
\text { (Mgal/yr) }\end{array}$ & $\begin{array}{l}\text { Part of model } \\
\text { unit in which } \\
\text { new with- } \\
\text { drawals occur }\end{array}$ \\
\hline FA & $\begin{array}{l}\text { Full allocation in } \\
\text { Atlantic City 800- } \\
\text { foot sand }\end{array}$ & NA & $\begin{array}{l}\text { Full allocation based on } 1998 \text { water-use for all wells in the } \\
\text { Atlantic City } 800 \text {-foot sand. All other aquifers pumping } \\
\text { at } 1998 \text { rates. }\end{array}$ & NA & NA & NA & NA \\
\hline S1 & Hamilton Township & 5034 & $\begin{array}{l}\text { New well } 10 \text { added for proposed increase. Two existing } \\
\text { wells pumping at full-allocation rate. }\end{array}$ & 768 & 429 & 1,197 & Confined \\
\hline $\mathrm{S} 2$ & $\begin{array}{l}\text { New Jersey American } \\
\text { Water Company }\end{array}$ & $5206 X$ & $\begin{array}{l}\text { Increase of } 625 \mathrm{Mgal} / \mathrm{yr} \text { at four existing wells. New well } 21 \\
\text { in Cohansey aquifer pumping at } 430 \mathrm{Mgal} / \mathrm{yr} \text {. }\end{array}$ & 925 & 625 & 1,550 & Confined \\
\hline S3 & Barnegat Township & 5301 & $\begin{array}{l}\text { New well } 6 \text { in deep part of Kirkwood-Cohansey aquifer } \\
\text { system. }\end{array}$ & 0 & 289 & 289 & Unconfined \\
\hline S4 & Cape May City & 5210 & $\begin{array}{l}\text { New well } 7 \text { for desalinization. Total of } 900 \mathrm{Mgal} / \mathrm{yr} \text { split } \\
\text { evenly between existing well } 6 \text { and new well } 7 \text {. }\end{array}$ & 415 & 485 & 900 & Confined \\
\hline S5 & Atlantic City MUA & 5306 & $\begin{array}{l}\text { New well } 27 . \text { Total of } 900 \mathrm{Mgal} / \mathrm{yr} \text {, split evenly between } \\
\text { existing wells } 14 \text { and } 25 \text { and new well } 27 .\end{array}$ & 730 & 170 & 900 & Confined \\
\hline S6 & $\begin{array}{l}\text { Little Egg Harbor } \\
\text { Township }\end{array}$ & 5037 & $\begin{array}{l}\text { New well } 11 \text { added for proposed increase. Three existing } \\
\text { wells pumping at full-allocation rate. }\end{array}$ & 577 & 116 & 693 & Confined \\
\hline S7 & Stafford Township & 5038 & $\begin{array}{l}\text { Three new wells }(8,9 \text {, and } 10) \text { pumping equal amounts } \\
\text { from the deep part of Kirkwood-Cohansey aquifer system } \\
\text { updip from confining unit limit. Existing wells pumping } \\
\text { at full allocation from the Atlantic City } 800-\mathrm{ft} \text { sand. }\end{array}$ & 653 & 756 & 1,409 & Unconfined \\
\hline
\end{tabular}


of the CPOPT model are documented in Pope and Gordon (1999).

The CMAC model is a fine-scale model of the Atlantic City 800-foot sand nested within the regional CPOPT model. The CMAC model was used to represent the ground-water flow in the Atlantic City 800-foot sand in Cape May County at a scale that is appropriate for particle-tracking analysis. Pathlines and travel times of particles placed along the $250-\mathrm{mg} / \mathrm{L}$ isochlor in the Atlantic City 800-foot sand were tracked towards discharge locations at production wells in Stone Harbor (fig. 1). The proposed increase in withdrawals for Cape May City (scenario 4) is for desalination, and simulated withdrawals were made from the seawater side of the $250-\mathrm{mg} / \mathrm{L}$ isochlor. The CMAC model was used to evaluate the effects of the increased withdrawals for desalination on the movement of the $250-\mathrm{mg} / \mathrm{L}$ isochlor in the Atlantic City 800 -foot sand. The hydrogeology of the Atlantic City 800-foot sand in the Cape May area and the design and calibration of the CMAC model are documented in Voronin and others (1996).

\section{Ground-water withdrawal data}

In the full-allocation simulation, withdrawals from the Atlantic City 800-foot sand were set at full-allocation rates as of 2004, and withdrawal rates in all other Coastal Plain aquifers were set at reported 1998 rates. The distribution of fullallocation withdrawals among a group of wells corresponding to a single NJDEP permit was determined using the percentage of the reported 1998 withdrawals that was produced by each of the individual wells. That is, a well that is pumping at 50 percent of the 1998 withdrawals for a permit was estimated to pump 50 percent of the full-allocation withdrawals. In cases where only monthly allocation numbers were available for the Atlantic City 800-foot sand, annual allocations were estimated by multiplying the monthly allocation by 12 .

\section{Simulation of potentiometric surfaces, drawdowns, and flow budgets}

\section{RASA model}

The estimated potentiometric surfaces using the RASA model for the Atlantic City 800-foot sand under full allocation and those generated for each scenario are shown in figure 3. The estimated potentiometric surface is calculated by subtracting the difference between the 1998 calibrated potentiometric surface and the potentiometric surface measured in 1998 from the simulated potentiometric surface for each scenario. The estimated potentiometric surfaces show the overall effect of the proposed increase in withdrawals on the regional resource. For each scenario, the locations of the existing and proposed wells associated with the allocation permit for which the increase is requested are shown in red. All other wells active during the simulation are shown in blue. The simulated incremental drawdowns resulting from each scenario are shown in figure 4. The full-allocation simulated drawdown map shows the drawdown from simulated 1998 conditions to full allocation. The simulated drawdowns for successive scenarios 1 through 7, each of which includes drawdown from the previous scenario, are shown in figure 4 . The cumulative simulated drawdown from full allocation for each scenario and the estimated potentiometric surface under full allocation simulated using the RASA model is shown in figure 5.

Flow budgets for the freshwater part of the aquifer under full allocation and in each of the seven scenarios are shown in figure 6 . The flows from various sources to the freshwater part of the Atlantic City 800-foot sand [in cubic ft per second (cfs)] for full allocation conditions and for each scenario are shown in figure $6 \mathrm{a}$. The incremental change in flow from the previous scenario for each source for each scenario is shown in figure $6 b$. The change in flow, for each source, from the full-allocation condition is shown in figure $6 \mathrm{c}$. The area for which the flow budgets are calculated and a conceptual cross section showing the flow-budget terms are shown in figure 7 . In areas updip from the updip limit of the confining unit overlying the Atlantic City 800-foot sand (fig. 1), the Kirkwood-Cohansey aquifer system was simulated in the RASA model using two model layers. The deeper of these two layers represents the Kirkwood-Cohansey aquifer system in areas updip from the limit of the overlying confining unit and the Atlantic City 800foot sand in areas downdip of the limit line. The shallower of the two layers represents the unconfined Kirkwood-Cohansey aquifer system. The flow term "From overlying unconfined Kirkwood-Cohansey aquifer system" refers to flow from the unconfined Kirkwood-Cohansey aquifer system (which overlies the Atlantic City 800-foot sand) vertically downward into the Atlantic City 800-foot sand. The flow term "From unconfined aquifer updip" refers to flow within the model layer representing the Atlantic City 800-foot sand in areas where it is unconfined and the Kirkwood part of the Kirkwood-Cohansey aquifer system. The updip limit line of confining unit overlying the Atlantic City 800-foot sand is shown in blue on figures 1, 3, 4, and 5. The flow term "From underlying Piney Point aquifer" represents vertical flow from the underlying Piney Point aquifer to the Atlantic City 800-foot sand. The flow term "From 250-mg/L saltwater zone" represents flow from the zone within the Atlantic City 800-foot sand where the chloride concentration in the water is assumed to be greater than 250 $\mathrm{mg} / \mathrm{L}$. This zone corresponds to the area east and south of the 250-mg/L isochlor shown in black on figures 1, 3, 4, and 5. The flow term "From Delaware Bay" represents flow from the area in Delaware Bay where the Atlantic City 800-foot sand may be unconfined beneath the bay and, therefore, is in contact with saltwater.

\section{CPOPT model}

The potentiometric surfaces simulated by the CPOPT model are similar to those simulated by the RASA model, but because of the larger model grid size of the CPOPT model, the cones of depression simulated by the CPOPT model are not as 

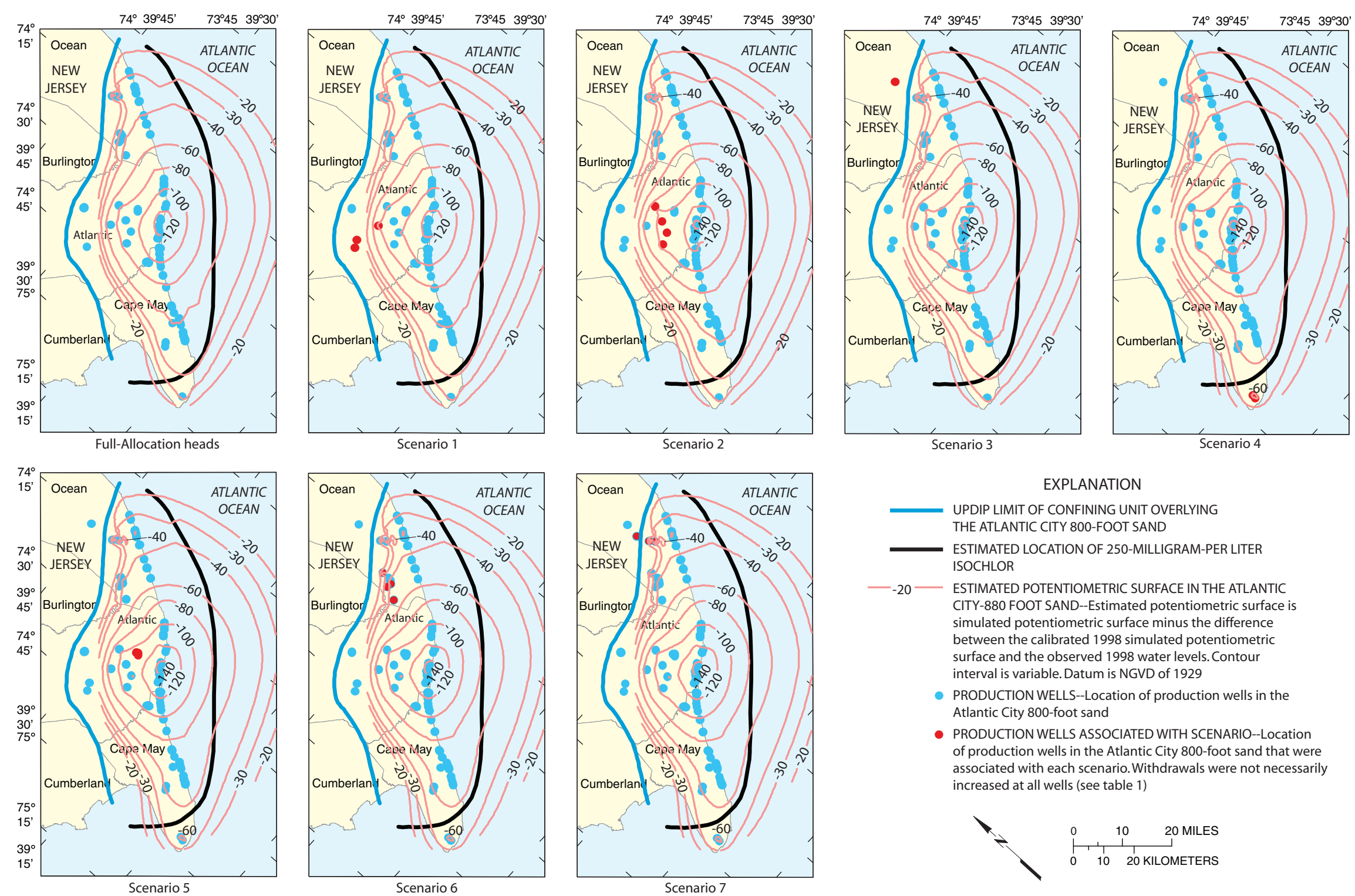

\section{EXPLANATION}

UPDIP LIMIT OF CONFINING UNIT OVERLYING THE ATLANTIC CITY 800-FOOT SAND ESTIMATED
ISOCHLOR

- 20 - ESTIMATED POTENTIOMETRIC SURFACE IN THE ATLANTIC CITY-880 FOOT SAND--Estimated potentiometric surface is simulated potentiometric surface minus the difference between the calibrated 1998 simulated potentiometric surface and the observed 1998 water levels. Contour interval is variable. Datum is NGVD of 1929

- PRODUCTION WELLS--Location of production wells in the Atlantic City 800-foot sand

- PRODUCTION WELLS ASSOCIATED WITH SCENARIO--Location of production wells in the Atlantic City 800-foot sand that were associated with each scenario. Withdrawals were not necessarily increased at all wells (see table 1)

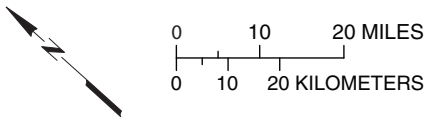

Figure 3. Estimated potentiometric surfaces for the Atlantic City 800-foot sand, New Jersey, using the RASA model. 

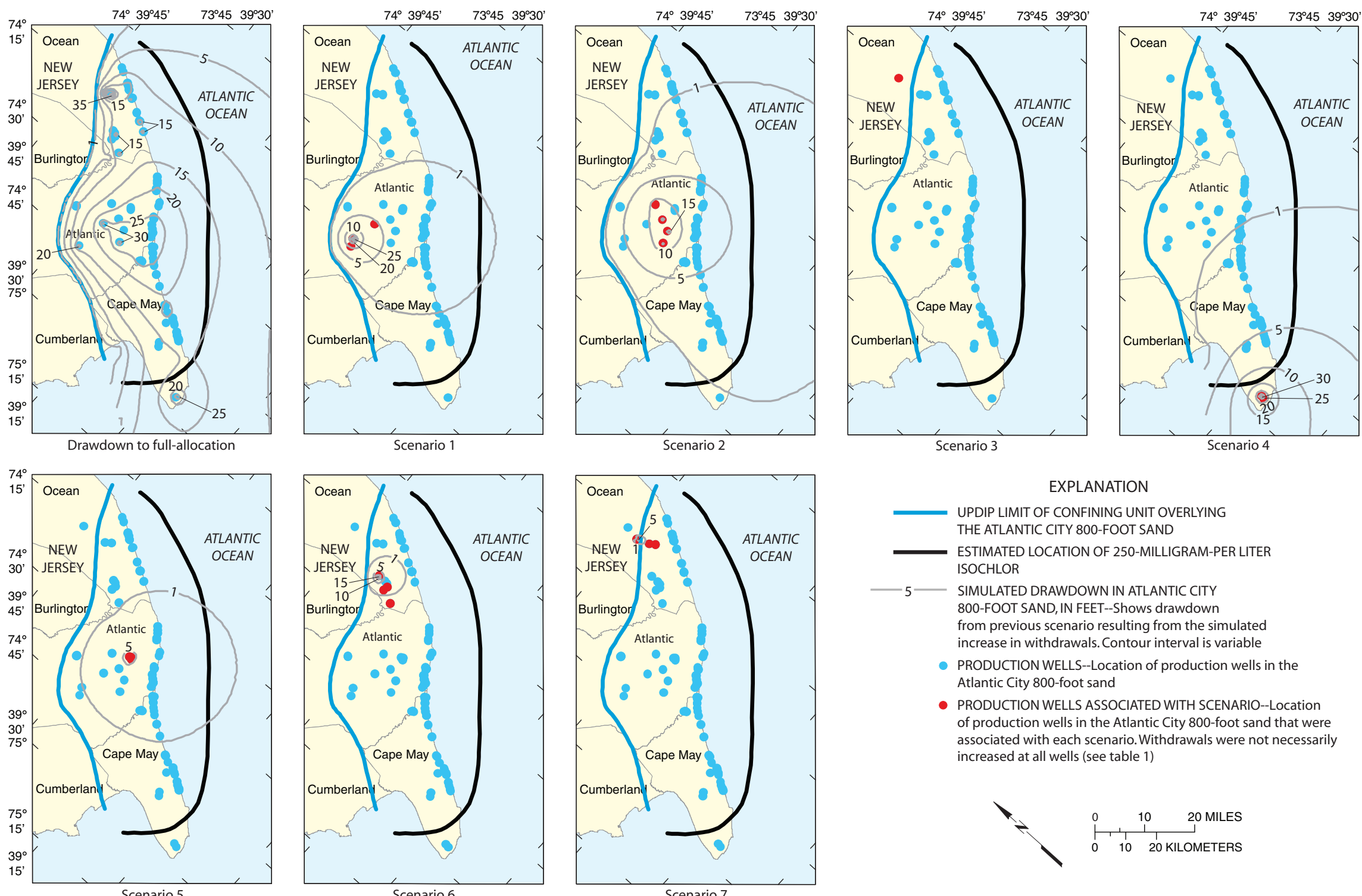

\section{EXPLANATION}

UPDIP LIMIT OF CONFINING UNIT OVERLYING THE ATLANTIC CITY 800-FOOT SAND

ESTIMATED LOCATION OF 250-MILLIGRAM-PER LITER ISOCHLOR

SIMULATED DRAWDOWN IN ATLANTIC CITY

800-FOOT SAND, IN FEET--Shows drawdown

from previous scenario resulting from the simulated

increase in withdrawals. Contour interval is variable

- PRODUCTION WELLS--Location of production wells in the Atlantic City 800-foot sand

- PRODUCTION WELLS ASSOCIATED WITH SCENARIO--Location of production wells in the Atlantic City 800-foot sand that wer associated with each scenario. Withdrawals were not necessarily increased at all wells (see table 1)

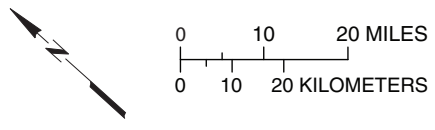

Scenario 7

Figure 4. Simulated drawdown from simulated 1998 conditions to full-allocation conditions and incremental drawdown from the previous scenario for scenarios 1 through 7 , Atlantic City 800 -foot sand, New Jersey. 

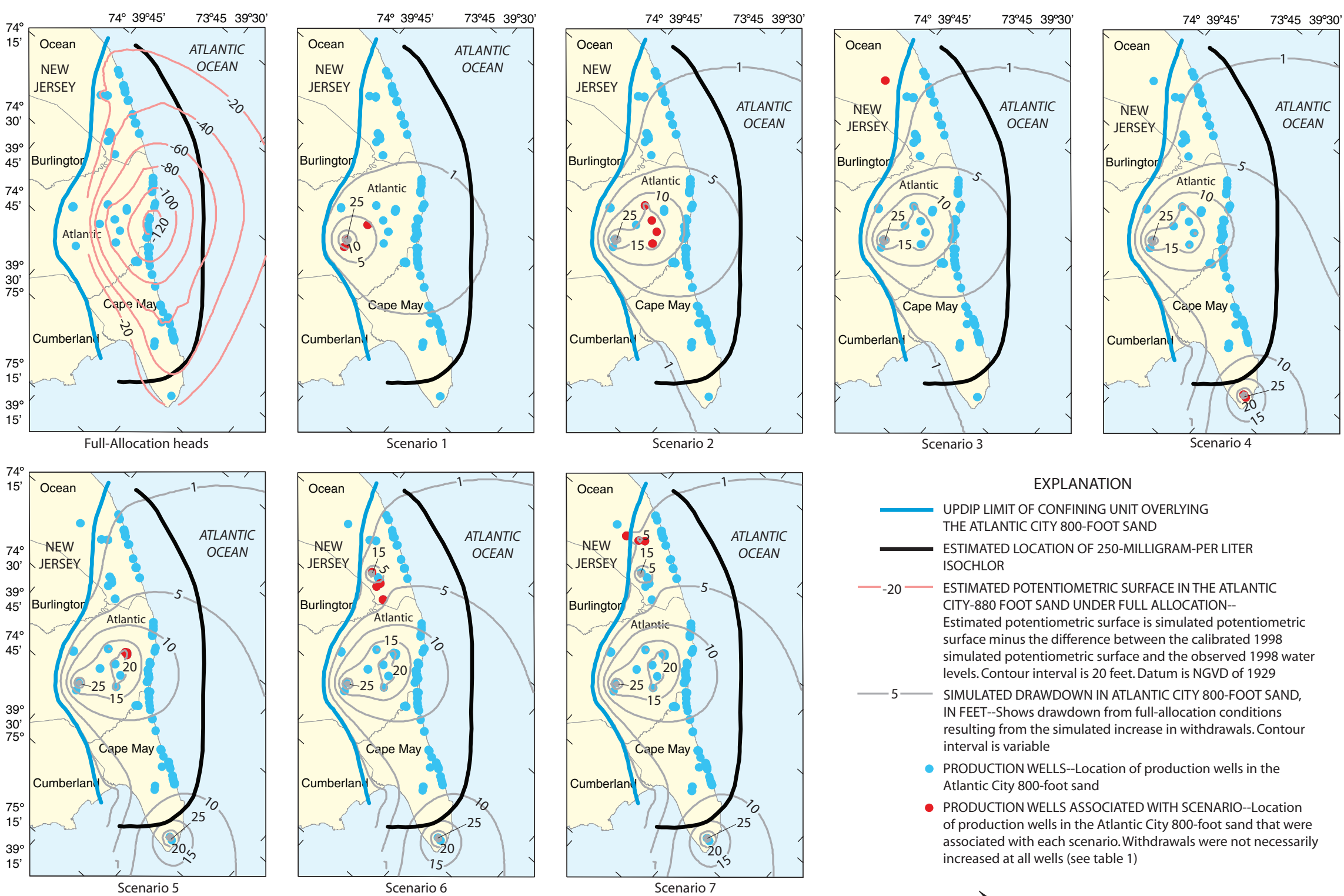

\section{EXPLANATION}

UPDIP LIMIT OF CONFINING UNIT OVERLYING THE ATLANTIC CITY 800-FOOT SAND

ESTIMATED LOCATION OF 250-MILLIGRAM-PER LITER ISOCHLOR

- -20 - ESTIMATED POTENTIOMETRIC SURFACE IN THE ATLANTIC CITY-880 FOOT SAND UNDER FULL ALLOCATION--

Estimated potentiometric surface is simulated potentiometric Estimated potentiometric suface is sinulated potentiomet simulated potentiometric surface and the observed 1998 water levels. Contour interval is 20 feet. Datum is NGVD of 1929 SIMULATED DRAWDOWN IN ATLANTIC CITY 800-FOOT SAND, IN FEET--Shows drawdown from full-allocation conditions resulting from the simulated increase in withdrawals. Contour interval is variable

- PRODUCTION WELLS--Location of production wells in the Atlantic City 800-foot sand

- PRODUCTION WELLS ASSOCIATED WITH SCENARIO--Location of production wells in the Atlantic City 800-foot sand that were associated with each scenario. Withdrawals were not necessarily increased at all wells (see table 1)

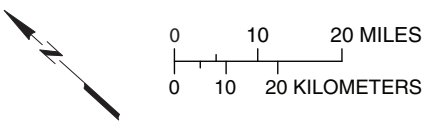

Figure 5. Estimated potentiometric surfaces resulting from full-allocation conditions and drawdown from full-allocation levels in successive scenarios 1 through 7 that each include the drawdown from previous scenarios, Atlantic City 800-foot sand, New Jersey. 
(a) Flow from sources

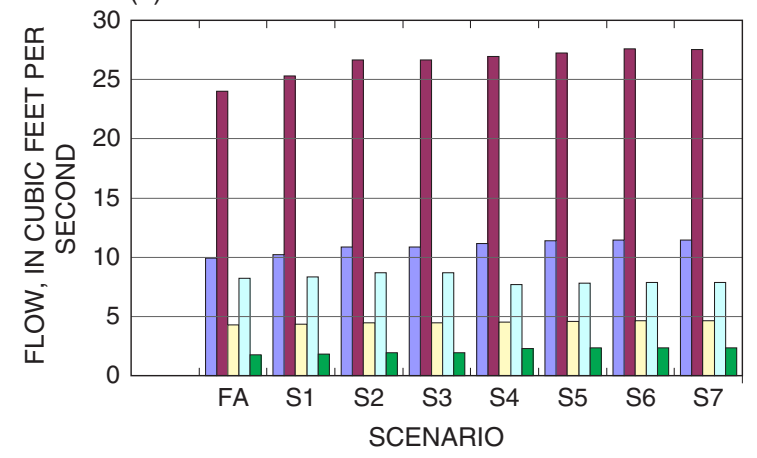

(b) Change from previous scenario

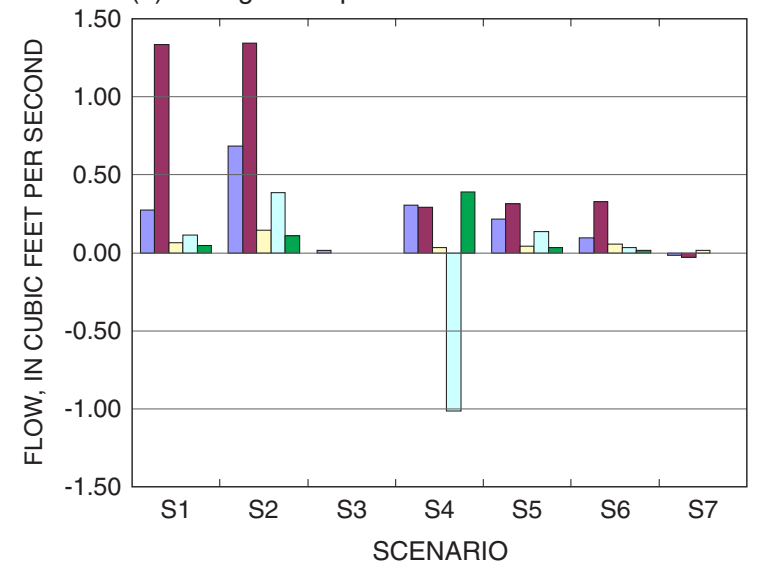

(c) Increase from Full Allocation

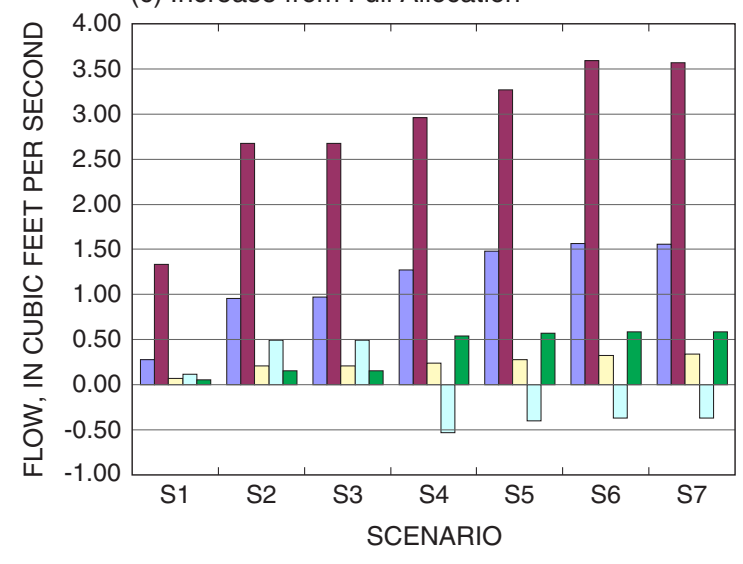

EXPLANATION

$\begin{array}{lc}\square \text { From overlying unconfined } & \square \text { From underlying Piney Point } \\ \text { Kirkwood-Cohansey } & \text { aquifer } \\ \text { aquifer system } & \square \text { From 250-milligram-per liter } \\ \square \text { From unconfined part of } & \text { saltwater zone } \\ \text { aquifer, updip } & \square \text { From Delaware Bay }\end{array}$

Figure 6. Flow budgets for the confined freshwater part of the Atlantic City 800 -foot sand, New Jersey, under full-allocation conditions and scenarios 1 through 7: (a) flow from sources, (b) change from previous scenario, (c) increase from full-allocation. (mg/L, milligram per liter; FA, Full Allocation, S1, indicates scenario number). deep or as wide as those simulated by the RASA model. In the Cape May area, the simulated potentiometric surfaces from the CPOPT model are similar to those from the RASA model. The location of the saltwater interface in the Atlantic City 800-foot sand under full-allocation conditions or in any of the increased withdrawal scenarios does not change substantially from the position simulated in 1988 (Pope and Gordon, 1999). Boundary conditions for the CMAC model were obtained laterally along the limits of the CMAC model and vertically from the overlying and underlying aquifers.

\section{CMAC model}

The simulated potentiometric surfaces and particle pathlines from the $250-\mathrm{mg} / \mathrm{L}$ isochlor in the Atlantic City 800-foot sand for full-allocation conditions and the seven scenarios produced by the CMAC model are shown in figure 8 . The location of the $250-\mathrm{mg} / \mathrm{L}$ isochlor and withdrawals for each scenario (shown as proportional circles) also are shown. Only in scenario 4, which has additional withdrawals for Cape May City, are the additional withdrawals located within the limits of the CMAC model. All other scenarios show the effects of withdrawals outside Cape May County (outside the limits of the CMAC model) on the movement of freshwater near the 250-mg/L isochlor in the Atlantic City 800-foot sand in Cape May County (fig. 1). Travel times from particle starting locations to discharge points for all scenarios are shown in table 2. The particle identifier numbers shown in table 2 are the same as those shown on fig. 8 .

\section{Limitations of the models}

All models are an approximation of the actual groundwater-flow system and are based on simplified representations of complex heterogeneous systems. Assumptions such as isotropy and vertical homogeneity within each layer are examples of simplified representations that can be a source of simulation errors. In addition, each of the three models used in this report were designed to answer specific questions and, therefore, have unique limitations. The RASA model was designed primarily to simulate freshwater flow in the confined part of the ground-water system of the New Jersey Coastal Plain on a regional scale. Simulation of flow to streams in the unconfined Kirkwood-Cohansey aquifer system is included in the RASA model as a boundary condition for deeper confined aquifers. Therefore, the simulated effects of scenario withdrawals on streamflow in streams overlying the KirkwoodCohansey aquifer system are limited. However, the simulation of the interaction between the Kirkwood-Cohansey aquifer system and the confined Atlantic City 800-foot sand is appropriate because the RASA model was designed to represent the confined aquifers. The CPOPT model has the same types of limitations as the RASA model but because the CPOPT model is more coarsely discretized, the limitations are greater. The CPOPT model, however, simulates the freshwater gradients 
West

Model layer representing

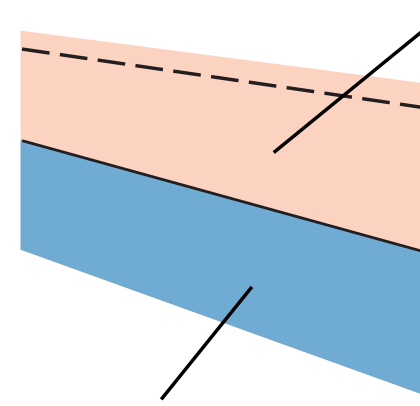

Model layer representing Kirkwood Formation and Atlantic city 800 -foot sand
Cohansey aquifer

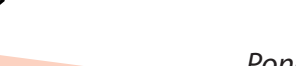

aquifer system

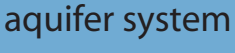

From overlying

unconfined Kirkwood-

Cohansey aquifer system

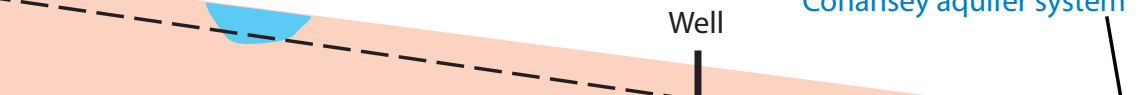

Kirkwodtcohansey

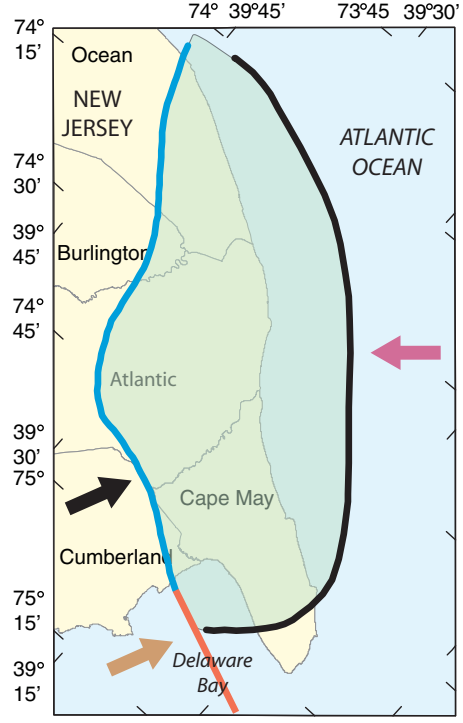

\section{EXPLANATION}

BUDGET AREA--Extent of budget area for the freshwater part of the Atlantic City 800 -foot sand UPDIP LIMIT OF CONFINING UNIT OVERLYING THE ATLANTIC CITY 800-FOOT SAND

ESTIMATED LOCATION OF 250-MILLIGRAM-PER LITER ISOCHLOR

\section{UPDIP LIMIT OF CONFINING UNIT OVERLYING THE}

ATLANTIC CITY 800-FOOT SAND IN DELAWARE BAY

7 FLOW--From 250-milligram-per liter saltwater zone

7 FLoW--From unconfined part of aquifer, updip

7 FLOW--From Delaware Bay

\section{$\stackrel{0}{0} \quad 10 \quad 20$ MILES}

1. 10 20 KILOMETERS

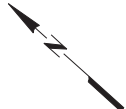

From underlying

Piney Point aquifer

Kirkwood-Cohansey - Atlantic Ocean

aquifer system

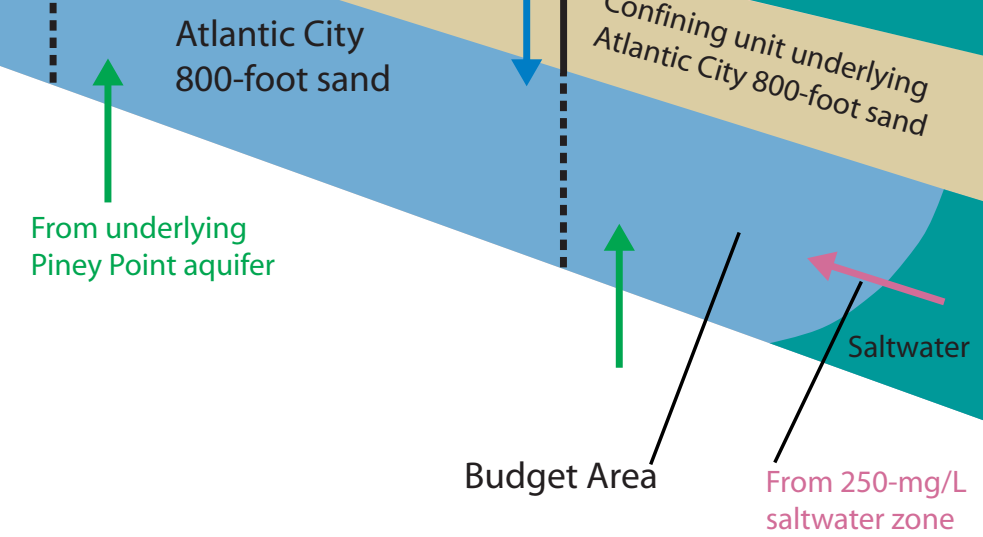

Figure 7. Conceptual cross section showing flow-budget area and flow terms for the Atlantic City 800-foot sand, New Jersey 

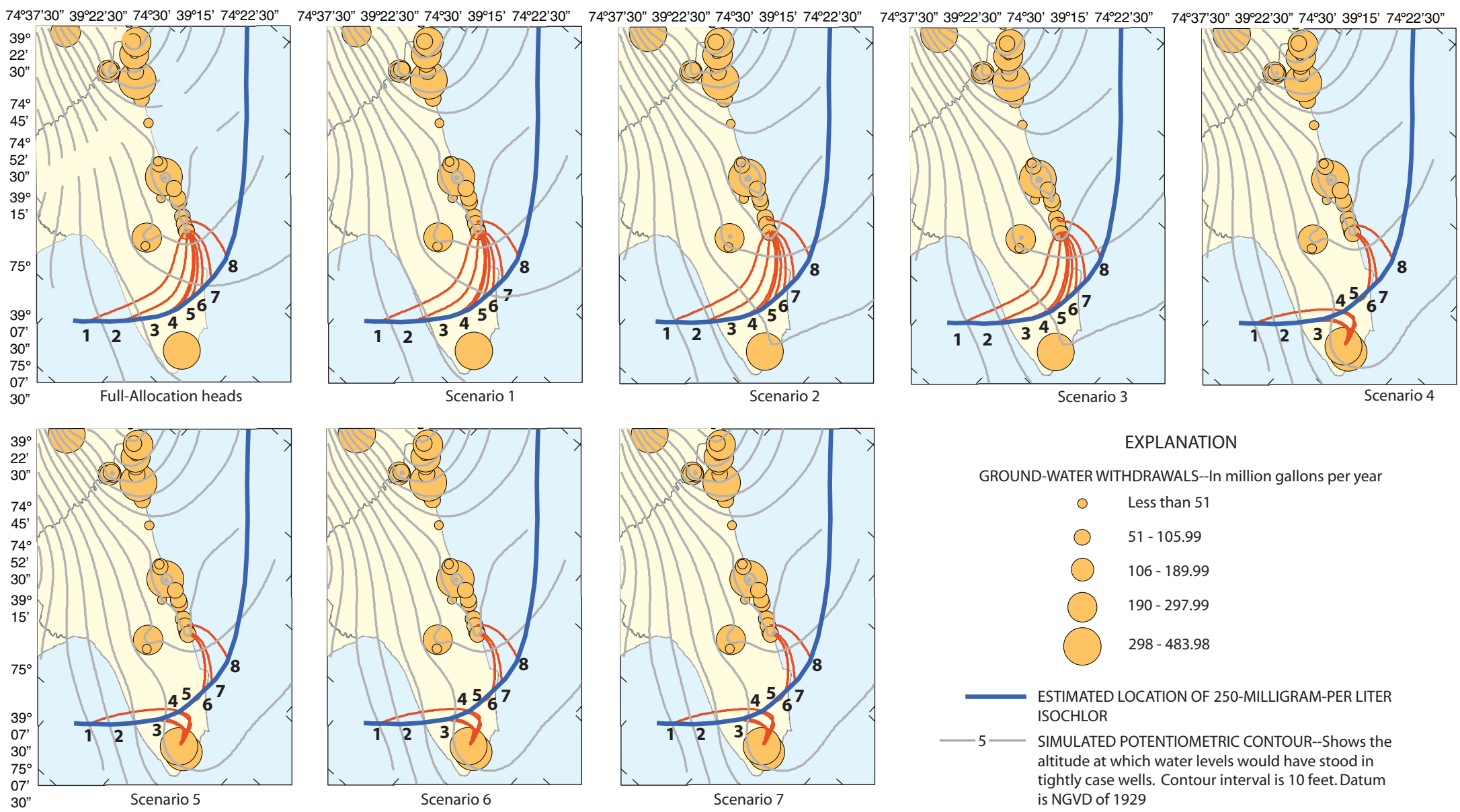

EXPLANATION

GROUND-WATER WITHDRAWALS--In million gallons per year

$$
\begin{array}{cc}
0 & \text { Less than } 51 \\
51-105.99 \\
106-189.99 \\
190-297.99 \\
298-483.98
\end{array}
$$
ESTIMATED LOCATION OF 250-MILLIGRAM-PER LITER ISOCHLOR
- 5- S SIMULATED POTENTIOMETRIC CONTOUR-Shows the altitude wich water levels would have stood in tigh case wells. Contour interval is 10 feet. Datum
1 - FLOW PATH OF WATER PARTICLE DETERMINED BY PARTICLE-TRACKING ANALYSIS OF SIMULATION RESULTS--Number is particle identifier

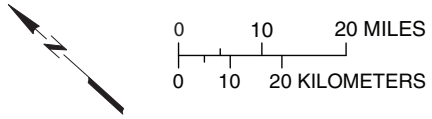

Figure 8. Simulated potentiometric surfaces and pathlines from the 250-milligram-per-liter isochlor using the Cape May Atlantic City 800 -foot sand model, Atlantic City 800 -foot sand, New Jersey. 
Table 2. Travel times of particles from the 250-milligram-per-liter isochlor to production wells, Atlantic City 800-foot sand, New Jersey.

[Labels S1 through S7 refers to scenario 1 through scenario 7]

\begin{tabular}{|c|c|c|c|c|c|c|c|c|}
\hline \multirow{2}{*}{$\begin{array}{l}\text { Particle } \\
\text { identifier }\end{array}$} & \multicolumn{8}{|c|}{ Travel time, in years } \\
\hline & Full allocation & S1 & S2 & S3 & S4 & S5 & S6 & S7 \\
\hline 1 & 1,700 & 1,600 & 1,500 & 1,500 & 2,100 & 2,100 & 2,100 & 2,100 \\
\hline 3 & 1,800 & 1,800 & 1,700 & 1,700 & 760 & 760 & 760 & 760 \\
\hline 4 & 1,500 & 1,500 & 1,400 & 1,400 & 1,100 & 1,100 & 1,100 & 1,100 \\
\hline 6 & 870 & 860 & 830 & 830 & 1,300 & 1,300 & 1,300 & 1,300 \\
\hline 7 & 730 & 720 & 710 & 710 & 920 & 910 & 910 & 910 \\
\hline 8 & 720 & 720 & 730 & 730 & 750 & 740 & 740 & 740 \\
\hline
\end{tabular}

near the saltwater-freshwater interface and is, therefore, more appropriate than the RASA model is for providing boundary conditions to the CMAC model near the interface in Cape May County. The CMAC model was designed with finer grid spacing than the RASA model and includes a thin clay layer within the Atlantic City 800-foot sand. This model was designed to estimate particle travel-times from the existing $250-\mathrm{mg} / \mathrm{L}$ isochlor to production wells. This travel time, however, is an estimate of the advective movement of the ground water near the interface and not of the actual interface itself, which was not simulated.

Because the increased withdrawals simulated in this report are from the confined aquifers or from deep within the unconfined aquifer, no attempt was made to quantify the effect on streamflow in individual streams in the outcrop area of the Kirkwood-Cohansey aquifer system. The simulation of these proposed increases is appropriate given the purposes for which the models were constructed and will not violate the assumptions associated with the boundary conditions of the original models.

\section{Simulated effects of ground-water withdrawals}

Simulation results for the full-allocation simulation and the seven scenarios representing proposed increases in groundwater withdrawals and the effects on water levels, drawdown in water levels, and travel times from the $250 \mathrm{mg} / \mathrm{L}$ isochlor to production wells are discussed in the following sections.

\section{Full-allocation conditions}

Under full-allocation conditions, the estimated potentiometric surface in the Atlantic City 800-foot sand developed a cone of depression centered on the barrier islands with minimum water levels of almost $120 \mathrm{ft}$ below NGVD of 1929 (fig. 3). Results from the RASA model show that the increase of withdrawals from 1998 rates to full-allocation rates caused water levels to decline by 15 to $30 \mathrm{ft}$ from simulated 1998 water levels on the barrier island and in onshore areas in Atlantic County. Declines of 15 to $25 \mathrm{ft}$ from simulated 1998 water levels occurred in southern Cape May County. Declines of greater than 35 to $40 \mathrm{ft}$ from simulated 1998 water levels occurred at the center of a local cone in Ocean County. Under full-allocation conditions, the wells at Stone Harbor will not be affected by the $250-\mathrm{mg} / \mathrm{L}$ chloride water for at least 720 years (table 2, fig. 8).

\section{Scenarios}

Simulation results for the seven scenarios representing proposed increases in ground-water withdrawals are discussed in the following sections.

\section{Scenario 1}

Scenario 1 represents a proposed increase of $429 \mathrm{Mgal} / \mathrm{yr}$ for the Hamilton Township Municipal Utility Authority (MUA) wells. All of the additional withdrawals were simulated at one proposed well location (well 10) in the Atlantic City 800-foot sand (table 1). Withdrawals from all existing wells were simulated at full-allocation rates. The Hamilton Township wells are located near the updip limit of the aquifer in Atlantic County. Simulated drawdowns of $10 \mathrm{ft}$ to greater than $25 \mathrm{ft}$ below the full-allocation potentiometric surface occurred in the vicinity of the well field (fig. 4) as a result of the increased withdrawals simulated using the RASA model. The flow budget from the RASA model (fig. 6a) shows that the additional water is supplied primarily by horizontal flow from the unconfined updip part of the Kirkwood-Cohansey aquifer system. This increase could affect streamflow near the updip limit of the aquifer; however, the effect would probably be distributed over a larger area than would be affected if 
withdrawals were made directly from the unconfined Kirkwood-Cohansey aquifer system.

Travel times for some of the particles tracked using the CMAC model from the $250-\mathrm{mg} / \mathrm{L}$ isochlor to production wells in Cape May County are slightly shorter than those in fullallocation conditions. The shortest travel time (particle 8) was still 720 years (table 2; fig. 8).

\section{Scenario 2}

Scenario 2 represents a proposed increase of $1,055 \mathrm{Mgal} / \mathrm{yr}$ for the New Jersey American Water Company (NJAWC) with $625 \mathrm{Mgal} / \mathrm{yr}$ of the total equally simulated at four wells in the Atlantic City 800-foot sand. The remaining $430 \mathrm{Mgal} / \mathrm{yr}$ is simulated at a proposed well location (well 21) in the unconfined Kirkwood-Cohansey aquifer system (table 1). These withdrawals caused simulated drawdown of 5 to $15 \mathrm{ft}$ from scenario 1 over much of the extent of the Atlantic City 800-foot sand in Atlantic County (fig. 4). The simulated cone of depression near Atlantic City deepened as much as 25 $\mathrm{ft}$ (fig. 3) using the RASA model. The flow budget produced from the RASA model (fig. 6a) shows that most of the additional water for scenario 2 is provided by horizontal flow from the unconfined updip part of the Kirkwood-Cohansey aquifer system. Most of the remaining water to supply the increased withdrawals is flow from the overlying Kirkwood-Cohansey aquifer system and from the saltwater part of the Atlantic City 800-foot sand.

The simulated increase in flow from the saltwater part of the aquifer gives warning of potential saltwater flow from the east. However, because the $250-\mathrm{mg} / \mathrm{L}$ isochlor is still more than 5 miles offshore from Atlantic City, the simulated problem is not immediate. Travel times from the $250-\mathrm{mg} / \mathrm{L}$ isochlor in Cape May County using the CMAC model decreased slightly from those in scenario 1 , with the shortest travel time being 710 years (table 2).

The effect of the additional $430 \mathrm{Mgal} / \mathrm{yr}$ withdrawals from the unconfined Kirkwood-Cohansey aquifer system cannot be adequately evaluated using the RASA model because that model was designed to simulate the confined aquifers in the New Jersey Coastal Plain. The effect of these withdrawals on streamflow and the water table near the well field can be evaluated using other methods.

\section{Scenario 3}

Scenario 3 represents a proposed increase of $289 \mathrm{Mgal} / \mathrm{yr}$ for the Barnegat Township MUA (table 1). Because the proposed well is updip from the area where the confining unit overlying the Atlantic City 800-foot sand pinches out (fig. 4), the withdrawals are assumed to come from the deep unconfined updip part of the Kirkwood-Cohansey aquifer system. In areas updip from the limit of the Atlantic City 800-foot sand, the Kirkwood-Cohansey aquifer system was modeled using two layers. The proposed well was modeled in the lower of these two layers. The drawdown and flow budget for the Atlantic City 800-foot sand generated using the RASA model for this scenario were essentially unchanged from the previous scenario (fig. 6a, b, and c). Because the simulated withdrawals are from the unconfined updip part of the Kirkwood-Cohansey aquifer, they affect simulated water levels in the overlying Kirkwood-Cohansey aquifer system and simulated flow to and from streams. The coarse grid size of the RASA model, however, is not appropriate to quantify these changes on a local scale. Travel times from the $250-\mathrm{mg} / \mathrm{L}$ isochlor to production wells in Cape May County (table 2; fig. 8) generated using the CMAC model were unchanged by the increased withdrawals from this proposed well in southern Ocean County from those shown in scenario 2 .

\section{Scenario 4}

Scenario 4 represents a proposed increase of $485 \mathrm{Mgal} / \mathrm{yr}$ in withdrawals for the Cape May City desalination wells located near the tip of the Cape May Peninsula. The total withdrawals for desalination are $900 \mathrm{Mgal} / \mathrm{yr}$ to be taken equally from two wells (existing well 6 and proposed well 7) (table 1). Using the RASA model, the increase causes additional drawdown from the previous scenario of 10 to $30 \mathrm{ft}$ in the onshore part the Atlantic City 800-ft sand in Cape May County where the $250-\mathrm{mg} / \mathrm{L}$ isochlor is present (fig. 4).

Because the flow budget area in the RASA model was defined for the Atlantic City 800-foot sand as the freshwater part of the aquifer, the Cape May withdrawals do not occur inside the flow budget area. Therefore, the changes to the flow-budget graphs resulting from this increase (fig. 6b) are different from those of other scenarios in that the increased demand causes flow to change direction toward the saltwater zone. The negative value of the flow term "From 250-mg/L saltwater zone" indicates that water flows out of the flowbudget area toward the saltwater zone to provide the additional water for this scenario. Small increases in flow from above, from updip, and from the bay into the flow budget area also provide the additional water.

The simulated travel times and pathlines of the particles from the $250-\mathrm{mg} / \mathrm{L}$ isochlor to production wells in Cape May County generated using the CMAC model are shown in table 2 and figure 8. In this scenario, the wells at Stone Harbor are not affected by the $250-\mathrm{mg} / \mathrm{L}$ chloride water for 750 years. The travel times for particle numbers 2, 3, and 4 are significantly shorter than under full-allocation conditions because these particles now move towards the Cape May City desalination wells rather than towards Stone Harbor. Travel times for particle numbers 1, 5, 6, and 7 are longer in this scenario than under full-allocation conditions because of changing flow patterns that occur from the addition of the desalination wells. Travel time for particle 8 (the particle with the shortest travel time under full-allocation conditions) to the Stone Harbor wells is basically unaffected (travel time increases slightly to 750 years) by the increase in withdrawals for desalination. 
Increased flow into the flow-budget area is from updip areas, the overlying aquifers, and from Delaware Bay (fig. $6 b)$. Flow from the Delaware Bay is of concern because of the potential for higher concentrations of chloride. The location of the outcrop of the Atlantic City 800-foot sand under the Delaware Bay is not clearly known and is estimated to be farther west than particle 1 shown on figure 8 . The travel time for this particle to the Cape May desalination wells is simulated to be 2,100 years.

\section{Scenario 5}

Scenario 5 represents a proposed increase of $170 \mathrm{Mgal} / \mathrm{yr}$ for the Atlantic City MUA (table 1). Withdrawals are at equal rates from a proposed well (well 27) and two existing wells (14 and 25). Drawdown from the previous scenario generated by the RASA model ranges from 0 to more than $5 \mathrm{ft}$ over almost all of the Atlantic City 800-foot sand in Atlantic County (fig. 4). The flow budget from the RASA model (fig. 6 ) shows that most of the additional water for this scenario comes from the unconfined updip part of the KirkwoodCohansey aquifer system and from the overlying KirkwoodCohansey aquifer system.

Travel times from the $250-\mathrm{mg} / \mathrm{L}$ isochlor to production wells in Cape May County (table 2; fig. 8) simulated using the CMAC model were not greatly affected by the increased withdrawals from central Atlantic County.

\section{Scenario 6}

Scenario 6 represents a proposed increase of $116 \mathrm{Mgal} / \mathrm{yr}$ for the Little Egg Harbor Township MUA wells (table 1). All of the additional water is withdrawn at the location of proposed new well 11. Simulated drawdown in the RASA model is limited to the immediate vicinity of the well field where more than $15 \mathrm{ft}$ of drawdown from the previous scenario occurs locally (fig. 4). Because the withdrawals are near the updip limit of the aquifer, most of the additional water for this scenario comes from the unconfined updip part of the Kirkwood-Cohansey aquifer system (fig. 6).

Travel times from the $250-\mathrm{mg} / \mathrm{L}$ isochlor to production wells in Cape May County (table 2; fig. 8) generated using the CMAC model were unchanged from scenario 5.

\section{Scenario 7}

Scenario 7 represents a proposed increase of $756 \mathrm{Mgal} / \mathrm{yr}$ for the Stafford Township MUA wells (table 1). All of the additional water is withdrawn from three proposed wells (8, 9 , and 10). These new wells are located updip from the line where the Atlantic City 800-foot sand becomes confined, and withdrawals are simulated from the lower model layer representing the deep part of the unconfined Kirkwood-Cohansey aquifer system. Because of the location of the increased withdrawals, very little additional drawdown from what was simu- lated in scenario 6 occurred in the Atlantic City 800-foot sand using the RASA model (fig. 4). Drawdown was limited to the immediate vicinity of the well field. The three proposed wells are outside the flow-budget area for the Atlantic City 800-foot sand and, therefore, do not substantially affect the flow budget of the confined Atlantic City 800-foot sand determined using the RASA model (fig. 6a, b, and c). The area was modeled as unconfined; therefore, additional withdrawals could affect streamflow associated with this aquifer. The effects of these withdrawals on streamflow associated with, and water levels in, the overlying Kirkwood-Cohansey aquifer system could not be evaluated using the RASA model.

Travel times from the $250-\mathrm{mg} / \mathrm{L}$ isochlor to production wells in Cape May County (table 2; fig. 8) generated using the CMAC model were unchanged from scenario 6.

\section{Effects of increased withdrawals on ground- water flow}

The model generated water levels that result from incremental increases from full-allocation withdrawals to an additional 1,825 Mgal/yr of withdrawals from the Atlantic City 800-foot sand (scenarios 1, 2, 4, 5, and 6) and 1,045 $\mathrm{Mgal} / \mathrm{yr}$ from the deep part of the Kirkwood-Cohansey aquifer system near the updip limit of the Atlantic City 800-foot sand (scenarios 3 and 7). These increases resulted in a decrease in water levels at the cone of depression near Atlantic City from almost $120 \mathrm{ft}$ below NGVD of 1929 to almost $140 \mathrm{ft}$ below NGVD of 1929 (fig. 3). Most of this decline occurred as the result of the increased withdrawals simulated in scenario 2 . Simulated water levels in Cape May County declined from altitudes ranging from -20 to $-100 \mathrm{ft}$ to altitudes ranging from -20 to $-120 \mathrm{ft}$ (fig. 3). These declines in water levels in Cape May County were caused mainly by the increased withdrawals simulated in scenario 4 (fig. 4).

Simulated drawdowns from full-allocation levels (fig. 5) were greatest in Atlantic County and southern Cape May County. The drawdown in Atlantic County was greater than $25 \mathrm{ft}$ near the Hamilton Township wells (S1) and greater than $10 \mathrm{ft}$ over much of the extent of the Atlantic City 800-foot sand in the rest of Atlantic County. These drawdowns were primarily the result of the increased withdrawals by the Hamilton Township (S1) and NJAWC (S2) wells. Smaller effects resulted from the increased withdrawals by the Atlantic City MUA (S5). The drawdown from full-allocation conditions in Cape May of from $5 \mathrm{ft}$ to more than $25 \mathrm{ft}$ was the result of the increased withdrawals by the Cape May City wells (S4).

The additional water to supply the increased withdrawals in scenarios 1 through 7 came primarily from horizontal flow from the deep unconfined updip part of the KirkwoodCohansey aquifer system, which accounted for 63 percent of the inflow. Flow from the overlying Kirkwood-Cohansey aquifer system into the Atlantic City 800-foot sand supplied 27 percent of the additional water. Flow from the Delaware Bay (10 percent) and from the underlying Piney Point aqui- 
fer (6 percent) accounted for the remaining inflows. Outflow was represented by an increase in flow towards the $250-\mathrm{mg} / \mathrm{L}$ isochlor as a result of the withdrawals of salty water in Cape May City (accounted for 6 percent decrease in total flow). The combined inflow from the Kirkwood-Cohansey aquifer system supplied 90 percent of the new withdrawals. Because the withdrawals were made from the confined part of the aquifer, the effect on streamflow was not as great as it would have been had the withdrawals come directly from the unconfined part of the Kirkwood-Cohansey aquifer system. The effect of withdrawals from the confined part of the aquifer would probably be distributed over a larger area in the unconfined part because of the intervening confining unit and would likely have less effect on streamflow in the individual streams nearest the proposed withdrawals.

The travel times of particles from the $250-\mathrm{mg} / \mathrm{L}$ isochlor to production wells in Stone Harbor were longer than those for full-allocation conditions as a result of the additional withdrawals for scenarios 1 through 7 (fig. 8). Withdrawals for scenarios 1,2,5, and 6 caused the saltwater to move slightly faster towards the production wells than did withdrawals in the other scenarios. These effects were small compared to the effects on travel time caused by the increased withdrawals in scenario 4 by the Cape May City desalination wells, which either diverted water towards the production wells or increased the travel time towards the Stone Harbor production wells.

\section{Summary and Conclusions}

There are concerns about the long-term sustainability of the Atlantic City 800-foot sand in southeastern New Jersey and its ability to supply water for projected future growth. Recent (2004) concerns about streamflow depletion have caused water-resource managers to consider a shift away from use of the unconfined Kirkwood-Cohansey aquifer system to the confined Atlantic City 800-foot sand. Threats to the sustainable water supply in the Atlantic City 800-foot sand include saltwater intrusion from the Atlantic Ocean and Delaware Bay and potential effects of withdrawals from the Atlantic City 800-foot sand on the overlying Kirkwood-Cohansey aquifer system. The U.S. Geological Survey (USGS), in cooperation with the New Jersey Department of Environmental Protection (NJDEP), conducted a study that included seven scenarios simulating proposed increases in withdrawals from the Atlantic City 800 -foot sand that are under review by the NJDEP.

Full-allocation ground-water withdrawals and the cumulative withdrawals for each of seven scenarios with proposed increases in withdrawals were simulated. Maps of simulated potentiometric surfaces, drawdowns, and pathlines from the $250-\mathrm{mg} / \mathrm{L}$ isochlor to production wells were produced along with flow budgets and travel times from saltwater zones (defined as areas where the chloride concentration is assumed to be above $250-\mathrm{mg} / \mathrm{L}$ ). All scenarios were based on full-allocation withdrawals for the Atlantic City 800-foot sand. The simulation of additional withdrawals for each scenario was cumulative; each scenario included the increase described for that scenario as well as for all previous scenarios. The simulations were done using three different ground-water-flow models, which included the New Jersey Coastal Plain Regional Aquifer System Analysis (RASA) model, the Coastal Plain Optimization model (CPOPT), and a model of the Atlantic City 800-foot sand in Atlantic County (CMAC). The increased withdrawals simulated in this study were made from the Atlantic City 800-foot sand or from deep within the unconfined Kirkwood-Cohansey aquifer system, and no attempt was made to quantify the effect of the increased withdrawals on streamflow in individual streams.

The increase in withdrawals from actual use in 1998 to full-allocation rates caused water levels to decline by 15 to $30 \mathrm{ft}$ from simulated 1998 water levels on the barrier islands and in onshore areas in Atlantic County. Declines of 15 to 25 $\mathrm{ft}$ also occurred in southern Cape May County. Large declines of more than $35 \mathrm{ft}$ occurred over localized areas in Ocean County. Under full-allocation conditions, the simulations showed that wells at Stone Harbor would not be affected by salty water for at least 720 years.

The proposed increase in withdrawals for Hamilton Township wells (scenario 1) resulted in simulated drawdown in the vicinity of the well field of $10 \mathrm{ft}$ to greater than $25 \mathrm{ft}$ below full-allocation potentiometric surfaces. Most of the additional water was supplied by horizontal flow from the unconfined updip part of the Kirkwood-Cohansey aquifer system. Travel times from the $250-\mathrm{mg} / \mathrm{L}$ isochlor to production wells in Cape May County were only slightly affected.

The proposed increase in withdrawals for the New Jersey American Water Company (NJAWC) wells (scenario 2) from the Atlantic City 800-foot sand caused simulated drawdown from scenario 1 of 5 to $15 \mathrm{ft}$ over much of the extent of the Atlantic City 800-foot sand in Atlantic County and deepened the cone of depression near Atlantic City. Most of the additional water for scenario 2 was provided by horizontal flow from the unconfined updip part of the Kirkwood-Cohansey aquifer system. Travel times from the $250-\mathrm{mg} / \mathrm{L}$ isochlor in Cape May County decreased slightly. The effect of the additional $430 \mathrm{Mgal} / \mathrm{yr}$ withdrawals by NJAWC wells (scenario 2) from the Kirkwood-Cohansey aquifer system cannot be adequately evaluated using the RASA model. The effect of these withdrawals on streamflow and the water table near the well field could not be determined.

In the scenario for Barnegat Township wells (scenario 3 ), the proposed increase in withdrawals at a proposed well near the updip limit of the Atlantic City 800-foot sand was simulated. These withdrawals are assumed to be from the deep unconfined updip part of the Kirkwood-Cohansey aquifer system. The drawdown and flow budget for the Atlantic City 800foot sand for this scenario were essentially unchanged from the previous scenario because the withdrawals were made from the unconfined updip part of the Kirkwood-Cohansey aquifer system. 
Scenario 4 represents the proposed increase in withdrawals for the Cape May City Water Department wells for use in desalination. This increase caused additional simulated drawdowns of 10 to greater than $30 \mathrm{ft}$ from the previous scenario in the onshore part of Cape May County where the $250 \mathrm{mg} / \mathrm{L}$ isochlor is present. Most of the water to meet this increased demand came from a decrease in flow from the 250$\mathrm{mg} / \mathrm{L}$ chloride zone. In this scenario, the wells at Stone Harbor would not be affected by the $250-\mathrm{mg} / \mathrm{L}$ chloride water for at least 750 years. Travel times for three particles from the 250$\mathrm{mg} / \mathrm{L}$ isochlor were significantly shorter than in full-allocation conditions, but these particles now moved towards the Cape May City desalination wells rather than towards Stone Harbor wells. The simulated increase would not cause the $250-\mathrm{mg} / \mathrm{L}$ chloride water at particle 8 to reach the Stone Harbor wells any faster. Travel times for some particles were longer in this scenario than under full-allocation conditions.

Scenario 5 represents the proposed increase in withdrawals for the Atlantic City MUA wells. Simulated drawdown ranges from 0 to greater than $5 \mathrm{ft}$ over much of the extent of the Atlantic City 800-foot sand in Atlantic County. Most of the additional water for this scenario flowed horizontally from the unconfined updip part of the Kirkwood-Cohansey aquifer system and from the overlying Kirkwood-Cohansey aquifer system. Travel times from the $250-\mathrm{mg} / \mathrm{L}$ isochlor to production wells in Cape May County were not greatly affected by these increased withdrawals from central Atlantic County.

Increased withdrawals for the Little Egg Harbor Township MUA wells (scenario 6) resulted in simulated drawdown only in the immediate vicinity of the well field. Because the withdrawals are near the updip limit of the aquifer, most of the additional water for this scenario came from the unconfined updip part of the Kirkwood-Cohansey aquifer system. Travel times from the 250-mg/L isochlor to production wells in Cape May County were not affected by these withdrawals.

The proposed increase in withdrawals for Stafford Township MUA wells (scenario 7) caused very little drawdown from the previous scenario and did not substantially affect the flow budget of the confined Atlantic City 800-foot sand. Simulated drawdown was limited to the immediate vicinity of the well field. Because the area was modeled as unconfined, there could be effects on streamflow resulting from these withdrawals; however, the effects of these withdrawals on streamflow and water levels in the Kirkwood-Cohansey aquifer system could not be evaluated using the RASA model. Travel times from the 250-mg/L isochlor to production wells in Cape May County were not affected by these withdrawals.

As a result of the increased withdrawals, simulated water levels in the vicinity of Atlantic City decreased from almost $120 \mathrm{ft}$ below NGVD of 1929 to almost $140 \mathrm{ft}$ below NGVD of 1929. The additional withdrawals in scenario 2 caused most of this decline. The additional water to meet the increased withdrawals in scenarios 1 through 7 was primarily supplied by horizontal flow from the unconfined updip part of the Kirkwood-Cohansey aquifer system, which accounted for 63 percent of the inflow. In general, the travel times from the
250-mg/L isochlor to production wells in Stone Harbor would be longer as a result of all the additional withdrawals for scenarios 1 through 7 . The major change in simulated travel times was caused by withdrawals from Cape May City desalination wells, which either diverted water from the $250-\mathrm{mg} / \mathrm{L}$ isochlor towards the production wells or increased the travel time towards production wells.

\section{References Cited}

Lacombe and Rosman, 2001, Water levels in, extent of freshwater in, and water withdrawals from ten confined aquifers, New Jersey and Delaware Coastal Plain, 1998: U.S. Geological Survey Water-Resources Investigations Report 00-4143, 10 plates.

Martin, Mary, 1998, Ground-water flow in the New Jersey Coastal Plain: U.S. Geological Survey Professional Paper 1404-H, 146 p.

McAuley, S.D., Barringer, J.L., Paulachok, G.N., Clark, J.S., and Zapecza, O.L., 2001, Ground-water flow and quality in the Atlantic City 800-foot sand, New Jersey: New Jersey Geological Survey Report GSR 41, 86 p.

Pope, D.A., and Gordon, A.D., 1999, Simulation of groundwater flow and movement of the freshwater-saltwater interface in the New Jersey Coastal Plain: U.S. Geological Survey Water-Resources Investigations Report 98-4216, 159 p.

Sugarman, P.J., 2001, Hydrostratigraphy of the Kirkwood and Cohansey Formations of Miocene age in Atlantic County and vicinity, New Jersey: New Jersey Geological Survey Report GSR 40, 26 p.

Voronin, L.M., Spitz, F.J., and McAuley, S.D., 1996, Evaluation of saltwater intrusion and travel time in the Atlantic City 800-foot sand, Cape May County, New Jersey, 1992, by use of a coupled-model approach and flow-path analysis: U.S. Geological Survey Water-Resources Investigations Report 95-4280, 38 p.

Voronin, L.M., 2003, Documentation of revisions to the Regional Aquifer System Analysis model of the New Jersey Coastal Plain: U.S. Geological Survey Water-Resources Investigations Report WRIR 03-4268, 49 p.

Zapecza, O.S., Voronin, L.M., and Martin, Mary, 1987, Ground-water withdrawal and water-level data used to simulate regional flow in the major Coastal Plain aquifers of New Jersey: U.S. Geological Survey Water-Resources Investigations Report 87-4038, 120 p., 10 pl.

Zapecza, O.S., 1989, Hydrogeologic framework of the New Jersey Coastal Plain: U.S. Geological Survey Professional Paper 1404-B, 47 p., 24 pl. 